\title{
Moving out of the bottom of the economy? Constraints to firm transition in the Indian informal manufacturing sector
}

Rajesh SN Raj ${ }^{1}$ and Kunal Sen $2,3^{*}$

* Correspondence: kunal.sen@ manchester.ac.uk

${ }^{2}$ Global Development Institute, University of Manchester,

Manchester, UK

${ }^{3}$ Global Development Institute, Oxford Road, Manchester M13 9PL, UK

Full list of author information is available at the end of the article

\begin{abstract}
The predominant type of firms in developing countries is small family firms and the self-employed in the informal sector. Very few family firms make the transition to larger firms employing non-family labour. In this paper, we examine the reasons for the low presence of firms employing non-family labour in the informal sector, using a firm-level data set drawn from nationally representative repeated cross-sectional surveys of the Indian informal manufacturing sector. We find that the key constraint to firm transition is firm capabilities, followed by the level of urbanisation, access to electricity and roads, and human capital, with financial constraints playing a lesser role. JEL codes: $017, \mathrm{~L} 25, \mathrm{D} 22$
\end{abstract}

Keywords: Informal sector, Firm transition, Firm growth, India

\section{Introduction}

The predominant type of firms in developing countries is small family firms and the self-employed in the informal sector, which contribute to the bulk of production and employment in the economy (Gollin 2008). ${ }^{1}$ These firms tend to be the least productive among all firms in the manufacturing sector, and the individuals that own, manage and work in these enterprises comprise a large proportion of the urban working poor in developing countries. The majority of these firms are not able to grow in size and make the transition to larger firms which employ non-family wage labour (De Neve 2005; Woodruff 2012). Yet, the difference in productivity between small family firms and the larger firms employing wage labour is large-in India's case, larger firms in the informal sector, employing 6-10 wage workers are $40 \%$ more productive than small family firms with no wage workers (Raj and Sen 2016). The preponderance of small family firms located in the informal sector of developing economies is an important reason why aggregate productivity in these economies remains so low, relative to that of advanced market economies (Hsieh and Klenow 2009). For many informal household enterprises, the transition to larger enterprises in the informal sector could be a route out of poverty, as well as providing employment for a large proportion of unskilled workers in urban and semi-urban areas. ${ }^{2}$

What explains why some family firms can make the transition to larger firms in the informal sector and others cannot? The determinants of firm growth in the informal

(c) 2016 Raj and Sen. Open Access This article is distributed under the terms of the Creative Commons Attribution 4.0 International icense (http://creativecommons.org/licenses/by/4.0/), which permits unrestricted use, distribution, and reproduction in any medium provided you give appropriate credit to the original author(s) and the source, provide a link to the Creative Commons license, and indicate if changes were made. 
sector of developing countries remain less understood, with much of the previous literature focusing on firm growth in the formal sector (Gang 1992; Variyam and Kraybill 1992). A wide set of factors has been seen as constraints to small firm growth in the formal sector, such as the lack of access to external finance (Mead and Liedholm 1998; Rijkers et al. 2010), the lack of capabilities in small firms that allow them to compete with large firms (Arend 2014; Schmitz 1982), the lack of access to networks and locational disadvantages (Mean 1984; Schmitz and Nadvi 1999; Rijkers et al. 2010), human capital (Nafziger and Terrell 1996; Burki and Terrell 1998) and infrastructural constraints (Aterido et al. 2011). In this paper, we assess the role of financial constraints, firm capabilities, location and geographical factors, and infrastructure and human capital in explaining the transition of firms in the informal sector from small family firms to larger firms employing wage labour.

Our empirical context is the Indian informal manufacturing sector. The formal manufacturing sector in India is taken to be definitionally equivalent to the organised sector, which comprises firms that are registered under the Factories Act of 1948 of the Government of India (Kulshreshtha 2011). Firms have to register with the Indian government under the Factories Act if they employ ten or more workers and use electricity in their operations, or if they employ 20 or more workers without the use of electricity in their operations (Pais 2008). The Factories Act regulates the conditions of work in the formal manufacturing sector, including minimum safety, sanitary, health and welfare standards, as well as stipulating regulations on hours of work, leave with wages and holiday provisions for workers, which employers in the formal sector need to follow or face stiff penalties (NCEUS 2009). The informal manufacturing sector, by default, comprises firms that fall outside the scope of the Factories Act; they generally do not pay taxes and are outside the purview of government regulations (Kanbur 2011). ${ }^{3}$

The informal sector is very large in India, with about 75 per cent of manufacturing employment and 17 per cent of manufacturing output in the sector, and the majority of firms (about 86 per cent) in the Indian informal sector are family firms (NCEUS 2007; Mazumdar and Sarkar 2008; Raj and Sen 2016). The firms in the informal manufacturing sector in India range from pure household enterprises (PHEs), which are very small in size, to slightly larger enterprises using both family and non-family labour, which we call mixed household enterprises (MHEs), to even larger enterprises employing mostly non-family labour, which we call non-household enterprises (NHEs).

We use firm-level data drawn from representative all-India surveys of informal firms in the Indian manufacturing sector which are repeated cross sections for the years 2000-2001, 2005-2006 and 2010-2011 to examine firm transition in the Indian informal sector-that is, the extent to which access to finance, firm capabilities, infrastructure, and human capital can explain the likelihood of a firm being a MHE or NHE as compared to a PHE. In contrast to the evidence available from earlier studies, we find a lesser role for financial constraints in explaining the likelihood of a firm being a larger firm employing wage workers as compared to a small family firm. According to our study, firm capabilities significantly matter in explaining whether firms are more likely to be MHEs and NHEs rather than PHEs. We find that firms which maintain accounts and firms that are registered under any act or authority are more likely to make the 
transition to larger firms employing non-family labour. Our results also confirm the crucial role of location, infrastructure and human capital in determining whether a firm is a MHE or a NHE versus a PHE in the informal sector. The likelihood of a firm being in the MHE and NHE categories is higher among firms that are located in urban areas and those that are located closer to the state capital. We also find that transition is faster among firms that have access to better infrastructure, especially power. Our finding on the positive effect of education beyond the secondary level supports the crucial role of human capital on firm transition.

The rest of the paper is in five sections. In the next section, we provide a brief discussion of the literature on the possible determinants of firm transition in the informal sector. In Section 3, we discuss the data, describe our econometric methodology and discuss the empirical specification. Section 4 provides an array of descriptive statistics and presents the results of the empirical analysis. Section 5 concludes.

\section{Related literature}

A sizeable body of research has examined the factors driving (and preventing) small manufacturing firm transitions (Nichter and Goldmark 2009; Schmitz and Nadvi 1999 for a review of these studies). Four important factors have been highlighted: (a) access to finance; (b) firm capabilities; (c) locational and geographical factors; and (d) the contextual factors (e.g. the investment climate and business environment). Our attempt here is to provide a brief review of selected studies on the role of finance, firm capabilities, locational and geographical factors and infrastructure and human capital on firm growth.

(a) Access to finance: The access to and cost of finance is one of the factors that determine the ability of a firm to grow (Binks and Ennew 1996; Rajan and Zingales 1998; Oliveira and Fortunato 2006). Firms that face financial constraints are less likely to invest in fixed assets (Ojah et al. 2010; Winker 1999) and also lack the capabilities to innovate (Winker 1999). There is evidence that small firms are financially more constrained than large firms (Beck et al. 2008; Beck 2007; Kuntchev et al. 2012). The presence of greater financial constraints thus exerts a negative influence on the growth of small firms (Beck et al. 2005; Oliveira and Fortunato 2006). ${ }^{4}$ One estimate suggests that the presence of financial constraints is associated with a 10 percentage point reduction in growth of small firms (Beck et al. 2008).

While there are studies highlighting a clear role for financial constraints on entrepreneurial start-up, there are fewer consensuses on the significance of credit access for the subsequent growth and performance of small firms. Brown et al. (2005) show that small firms with access to credit grow more rapidly. Catao et al. (2009) find that financial deepening shifts the composition away from self-employment towards larger firms. Woodruff and Zenteno (2007) also show evidence of the high importance of access to credit on development of microenterprises. On the other side, studies also highlight the less important role played by financial constraints on firm growth. For instance, Daniels and Mead (1998), Johnson et al. (2002) and McPherson and Rous (2010) do not find compelling evidence to show that access to formal credit is a significant factor influencing 
firm growth. The preceding discussion thus seems to indicate that access to finance is a necessary but not a sufficient condition for small firm growth (Nichter and Goldmark 2009).

(b) Firm capabilities: In the resource-based view of firm capabilities, where the firm is not just an administrative unit, but a collection of productive resources (Penrose 1959), the capabilities of the managers of firms (which, in the case of the informal firm, are also the owners) are key to attaining competitive advantage and to firm expansion. Studies have used different indicators to represent firm capabilities. Indicators such as R\&D investment or purchase of specialised machinery used in previous studies are less applicable as measures of firm capability in the informal sector (Sher and Yang 2005; Yang and Huang 2005). A key source of information on technology and marketing for owners of informal firms are other firms, often in the formal sector, with whom they have subcontracting arrangements (Berry et al. 2002). Lall (1980) and Hill (1985) consider subcontracting as means by which technological improvements are transmitted from the large- to the small-scale sector. Subcontracting also helps firms in generating productive employment and higher incomes (Yasuda 2005), thereby acting as an important determinant of firm growth (Giunta et al. 2012).

Another indicator of firm capabilities in the informal sector context is the maintenance of accounts by the manager-the maintenance of accounts by a small informal firm may allow the owner-manager of the firm to access external finance via the presentation of these accounts to bank managers, and help overcome the constraints to their expansion. The registration of firms under a given Act or authority of the government also provides a proxy for firm capabilities as registered firms are able to access specialised training and acquire knowledge than non-registered firms. In a recent paper, Sharma (2014) finds that registration leads to 32 per cent gain in sales per employee and 56 per cent gain in value added per employee for firms in the small-scale sector.

(c) Location and geographical factors: There exists substantial evidence on the positive role of locational and geographical factors on firm growth. Studies have used different indicators to capture the effect of location on small firm growth. Some studies associate urban location with faster firm growth. For instance, Bigsten and Gebreeyesus (2007) and Liedholm and Mead (1999) find that enterprises in urban areas grow more rapidly than those operating from rural areas.

Some studies have used measures of market accessibility such as access to transport and distance, cost and travel time to the main market as proxies for location, and examined their impact on firm growth. Shiferaw et al. (2013) find a positive relationship between the quality of transport infrastructure and enterprise performance in Ethiopia. The positive productivity effects of market accessibility for firms are also found for Spain (Holl 2012), the UK (Rice et al. 2006) and India (Lall et al. 2004).

(d) Infrastructure and human capital: There is ample evidence in the literature that infrastructure is critical to firm growth as it helps firms to get connected to core economic activities and access additional productive activities. Better infrastructure also helps firms to overcome the bottleneck of locating in backward areas by effecting a reduction in transaction costs. Available evidence point to a strong 
positive relationship between access to infrastructure and firm growth and productivity (Bigsten and Gebreeyesus 2007; Dollar et al. 2005). Some scholars established this relationship using access to electricity as a proxy for infrastructure (Rijkers et al. 2010) and some using road accessibility as an indicator of infrastructure (Shiferaw et al. 2013). There is overwhelming evidence at the firm level that human capital embodied in the owner of a firm or its workers (generally measured in terms of years of education, age or experience) promotes firm growth (Mead and Liedholm 1998; Van der Sluis et al. 2005; McPherson and Rous 2010). McPherson and Rous (2010) estimate that the firms in which the typical worker has had formal training have average annual growth rates that are about 2.3 percentage points higher than other firms.

\section{Empirical strategy, data and econometric methodology}

\subsection{Empirical strategy}

The objective of the study is to analyse the factors that explain the transition of firms across the entire continuum of firm size in the informal manufacturing sector. Firms in the Indian informal sector are broadly classified into three categories, based on the size of the enterprise and the type of labour used in the production process. They are (a) own-account manufacturing enterprises, which we call PHEs employing only family labour; (b) non-directory manufacturing establishments, which we call MHEs, employing at least one hired labour on a regular basis, but the total number of workers (including family labour) employed by them do not exceed five; and (c) directory manufacturing establishments, which we call NHEs employing 6-9 workers of which at least one would be a hired worker. ${ }^{5}$ These three categories of informal firms co-exist with the formal firms which are defined (by the Factory Act) to be employing ten or more workers. The PHEs are located mostly in the household premises, and thus represent the 'pure' informal sector, according to Mazumdar and Sarkar (2008). The majority of MHEs also fall into the 'pure' category of the informal sector though they use the service of a hired labour, who indeed could be partly a house servant. The NHEs employing 6-9 workers include small enterprises in modern manufacturing.

As Fig. 1 makes clear, the largest number of enterprises in the Indian informal manufacturing sector are PHEs, followed by MHEs, and then NHEs. The figure also shows that there is little evidence of greater transition of firms from PHEs to MHEs and NHEs from 2000-2001 to 2010-2011.

In this paper, our interest is to locate the factors that could explain the firm transition in the informal sector (i.e. from PHEs to MHEs and then to NHEs). Such a transition would also help in improving the overall productivity of manufacturing sector as lack of upward mobility of firms is argued to be a major hindrance affecting productivity of manufacturing sectors of developing countries (Gollin 2008). This is clearly evident in Figs. 2 and 3. There is a clear positive relationship between size and productivity, indicating that larger firms are more productive than small firms (Fig. 2). ${ }^{6}$ This is more obvious when we examine the productivity by enterprise type (Fig. 3). We find that the PHEs are the least productive category of firms in the sector followed by MHEs and NHEs and this difference in labour productivity has substantially increased between 2000-2001 and 2010-2011. Our estimations suggest that MHEs and NHEs are 


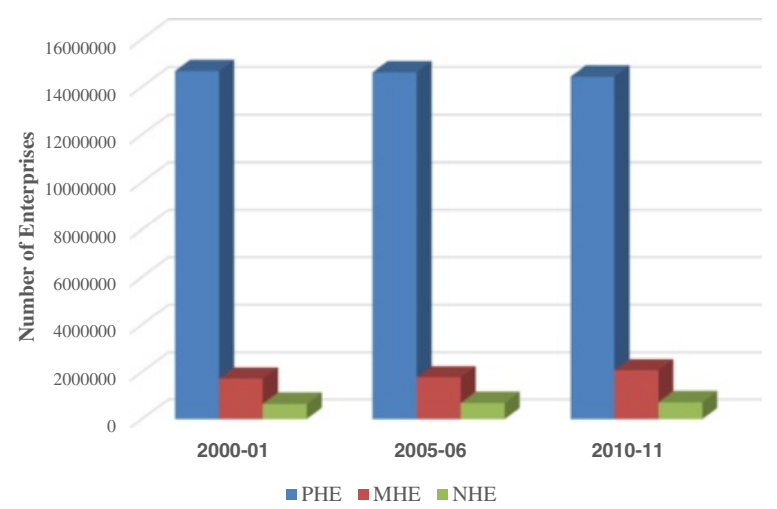

Fig. 1 Number of PHEs, MHEs and NHEs, 2000-2001 to 2010-2011. Note: a PHEs are pure household enterprises (PHEs) employing only family labour; mixed household enterprises (MHEs) are enterprises that employ at least one hired labour on a regular basis, but the total number of workers (including family labour) do not exceed five; and non-household enterprises (NHEs) are those employing 6-9 workers of which at least one would be a hired worker. $\mathbf{b}$ The estimation is performed using the survey weights provided by the NSSO. Source: our calculations, from NSSO unit-level data for 2000-2001 and 2010-2011

respectively 2.3 times and 2.5 times productive, respectively, than the PHEs in 20102011. This perhaps explains the overall low productivity of the informal manufacturing sector as the PHEs account for the bulk of the enterprises in the informal sector in India (Raj and Sen 2016). The significant difference in productivity across enterprise types also shows that the graduation of firms into higher size categories can significantly improve the productivity of firms in the informal manufacturing sector.

\subsection{Data}

Our main data sources are the surveys on the India's unorganised or informal manufacturing establishments. ${ }^{7}$ The National Sample Survey Organisation (NSSO) is the agency that collects unit-level data on various aspects of the enterprises in the informal manufacturing sector quinquennially, using a stratified random sampling procedure. These are nationwide enterprise-level surveys covering all the Indian states and

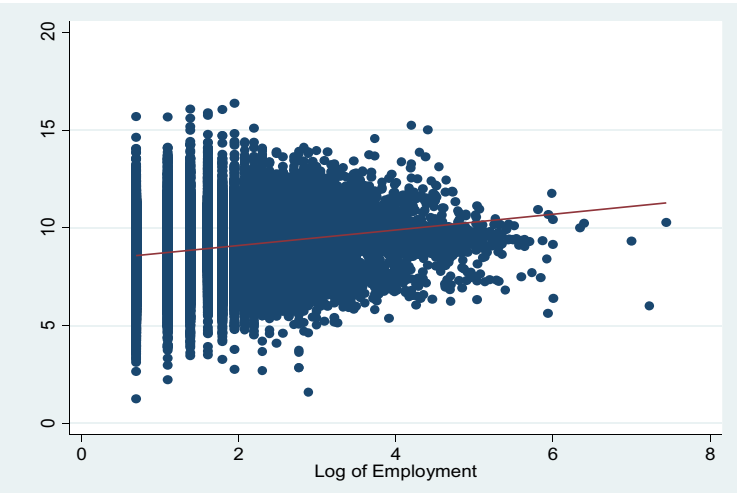

Fig. 2 Relationship between labour productivity and size, 2000-2001 to 2010-2011. Note: The estimation is performed using the survey weights provided by the NSSO. Source: our calculations, from NSSO unit-level data for 2000-2001, 2005-2006 and 2010-2011 


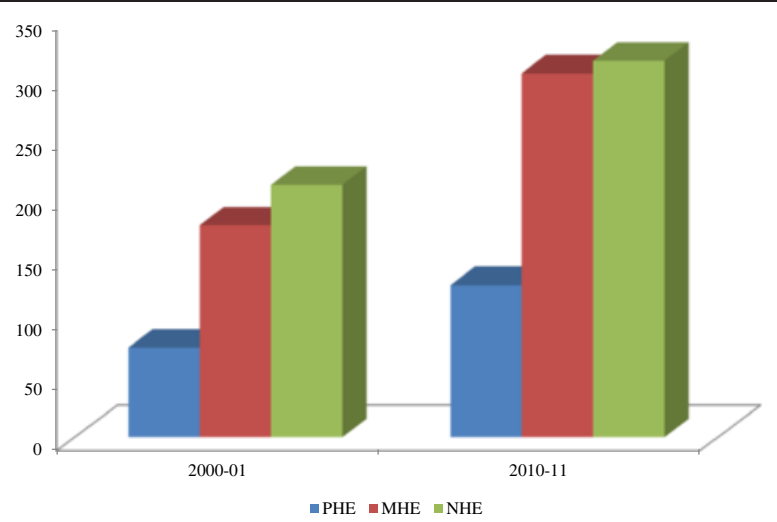

Fig. 3 Average labour productivity (in 2000) by enterprise type, 2000-2001 and 2010-2011. Note: a PHEs are pure household enterprises (PHES) employing only family labour; mixed household enterprises (MHES) are enterprises that employ at least one hired labour on a regular basis, but the total number of workers (including family labour) do not exceed five; and non-household enterprises (NHES) are those employing 6-9 workers of which at least one would be a hired worker. $\mathbf{b}$ The estimation is performed using the survey weights provided by the NSSO. Source: our calculations, from NSSO unit-level data for 2000-2001 and 2010-2011

union territories (UTs) and are stratified by district. Since most informal enterprises are not registered with any government authority, the NSSO uses a block enumeration approach to ensure a representative sample of the informal sector in every district.

Our analysis is based on the unit-level data for three years, 2000-2001, 2005-2006 and 2010-2011. The choice of time period for our study is governed by the fact that the data on some of the firm-specific variables used in the analysis are only available for these years. ${ }^{8}$ For our unit-level data, we had 294,736 firms in the pooled data set, across 22 industries, 364 districts, 15 major Indian states and three years. ${ }^{9}$

The National Industrial Classification (NIC) has also witnessed substantial changes over the last ten years. The NSSO data for 2000-2001 is based on NIC 1998 and for 2005-2006 is based on NIC 2004. The 2010-2011 round uses the NIC 2008 codes. We harmonised the whole data at the NIC 2008 codes and constructed twenty-two industry groups for all the three rounds in our data set.

Data on district-level variables are obtained from the 2001 Census of India.

\subsubsection{Limitations of the data}

As the objective of our study is to look at the transition of firms across the continuum of size classes in the informal manufacturing sector in India, ideally, we should be able to trace the progression of a firm over a specific period. However, the NSSO does not reveal the identity of the firm/plant in the unit-level data, and the same firms may not be surveyed in each round. Therefore, the lack of availability of panel data is a limitation of our analysis. Instead, we use repeated cross sections for the analysis.

\subsection{The model}

We use econometric analysis to formally test the role of financial constraint, firm capabilities, locational and geographical factors, and infrastructural and human capital variables on the upward progression of firms in the informal sector in India. We employ an ordered logit model to capture the firm transition in the informal sector. ${ }^{10}$ 
The dependent variable is firm type, denoted by $e$, which is an ordered categorical variable ranging from 1 to $3(1=\mathrm{PHE}, 2=\mathrm{MHE}$ and $3=\mathrm{NHE}) .{ }^{11}$ We assume that there is a latent variable $e^{*}$ given by the following expression:

$$
\begin{aligned}
e_{j, i, d, t}^{*}= & \alpha_{0}+\alpha_{1} \operatorname{FIN}_{j, i, d, t}+\sum_{k>1} \beta_{k} \operatorname{FCAP}_{j, i, d, t}+\sum_{l>1} \mu_{l} \mathrm{LOC}_{d, t}+\sum_{p>1} \phi_{p} \operatorname{INF}_{d, t}+ \\
& \lambda m \operatorname{STATUS}_{j, i, d, t}+\gamma_{i}+\delta_{t}+\varepsilon_{j, i, d, t}
\end{aligned}
$$

FIN is our measure of financial constraint that a particular firm faces. We use a direct measure to capture the firm's financial constraint. The NSSO asks the firms in its surveys if they have faced any constraint on their borrowing in the last year. We denote this variable CAPSHOR and code it as 1 if the firm faces a constraint and 0 if it does not. We would expect $\alpha_{1}$ to be less than zero if access to finance acts as a constraint on firm transition.

FCAP is a vector of four variables representing firm capabilities. The NSSO in its surveys asks the firms whether they work solely for a contractor (that is, they sell all their outputs to the contractor, who usually in this tied arrangement supplies them with inputs). We name this variable LINKAGE and code it as 1 if they work for a contractor and 0 if they do not. Our conjecture is that the firms that work for contractors are more likely to scale up their size as they may be needing the specialised skills that outside workers bring. The survey also asks the firms whether they receive any assistance from the government towards training and marketing. We label this variable ASSISTANCE and assign the code 1 if the firm received any assistance and 0 if it did not. We argue that any such type of assistance will be positively associated with firm transition in the informal sector. ACMAINT is another variable considered under the 'firm capabilities' dimension, which takes the value 1 if the firm maintains a regular account and 0 if it does not. Our contention is that firms that maintain account are better organised and are more likely to shift to the next size class in the informal sector. The NSSO surveys also ask the firms whether they have registered under any Act or authority. We maintain that being a part of an Act/authority could help the owner-manager to access and secure a range of financial and non-financial resources (information, knowledge, technology and finance) that are otherwise mostly unavailable to the firms in the informal sector. We denote this variable REGIS and code it 1 if they have registered under any Act and 0 if they did not. We envisage a positive relationship between REGIS and firm transition. ${ }^{12}$

The vector LOC contains four variables that encapsulate the locational and geographical features of firms. The four variables are LOCATION, URBAN, TRANSPORT and DISTANCE. LOCATION is a firm-level attribute intend to capture the benefits that a firm may derive by being located in urban areas. It is expected to capture differences among firms in access to better infrastructure and larger markets for skilled labour, raw materials and outputs. The NSSO surveys report whether the firms are located in rural or urban areas. LOCATION takes the value 1 if the firm is located in urban areas and 0 if the firm is located in rural areas. The expectation is that firms that are located in and around cities and towns (as a large market area) will experience faster expansion in size than their counterparts. URBAN is a district-level measure representing the level of urbanisation in the district where the firms are located, as measured by the share of 
urban population in total population. Our surmise is that higher the level of urbanisation in a district, higher will be the firm transition. We introduce two more districtlevel measures, TRANSPORT and DISTANCE. TRANSPORT indicates the access to the district in terms of a major transportation link, and it takes the value 1 if a national highway or a broad-gauge line passes through the district and 0 if neither of them passes through the district. DISTANCE signifies the remoteness of the district as captured by the distance of the district from the state capital. We expect that TRANSPORT will have a positive impact on firm transition and DISTANCE will have a negative impact on firm transition.

INF is a vector that includes infrastructural and human capital variables. Our attempt is to see whether differences in the availability of infrastructure and human capital influence the vertical expansion of firms in the informal sector. Five such variables, namely, ELEC, SHSCSTPOP, PRIMEDU, MIDGRADEDU and ROADVILLG, are identified. ELEC is a firm-specific variable while he other four variables are constructed at the district level. ELEC indicates whether the firm has access to electricity, and it takes the value 1 if it has access to electricity and 0 if it lacks access to it. SHSCSTPOP represents the proportion of Scheduled Castes (SCs) and Scheduled Tribes (STs) in total population, PRIMEDU captures the proportion of individuals who are educated at the primary level or below, MIDGRADEDU stands for the proportion of individuals educated at secondary level and above and ROADVILLG represents share of villages with paved approach road in total villages. We expect that a higher level of human capital as measured by high MIDGRADEDU and low PRIMEDU would have a positive effect on firm transition. On the other hand, social and economic backwardness as captured by SHSCSTPOP will have a negative effect on firm transition. ${ }^{13}$ We also envisage that better provision of infrastructure captured through the availability of power (ELEC) and better roads (ROADVILLG) would influence firm transition positively.

We also introduce a firm-specific control variable STATUS, which indicates whether the firm has been expanding in the past three years (STATUS $=1$ if the firm has been expanding and STATUS $=0$ if the firm has been stagnant or contracting). This variable captures the demand-side determinants of firm transition-clearly, a firm that has seen an increase in its sales is more likely to make the transition from PHE status to MHE status and then to NHE status than a firm which faces a stagnant or contracting market. The variables $\gamma_{i}$ and $\delta_{t}$ are the industry-specific fixed effects and the year-specific dummies, respectively. ${ }^{14}$

We use industry-specific effects to address the large differences in the distribution of PHEs, MHEs and NHEs that are observed across industries. For example, in unskilled labour-intensive industries such as beverages, only 1 per cent of informal firms are MHEs and NHEs. In comparison, 70 per cent of firms in capital-intensive industries such as transportation are MHEs and NHEs. This inter-industry variation in the distribution of PHEs, MHEs and NHEs reflects intrinsic differences in technological and skill requirements of the industry (with PHEs having lower levels of technology and skill than MHEs and NHEs).

The year dummies capture the possibility that economy-wide demand shocks may have an impact on firm transition. The subscript $j$ stands for firm, $i$ for industry, $d$ for district and $t$ for time. 
The link between the observed and the latent variables is given by

$$
\begin{gathered}
P\left(e_{i}=1 \mid v_{i}\right)=\theta\left(-\alpha_{0}-v_{i} \gamma\right) \\
P\left(e_{i}=2 \mid v_{i}\right)=\theta\left(\mu-\alpha_{0}-v_{i} \gamma\right)-\theta\left(-\alpha_{0}-v_{i} \gamma\right) \\
P\left(e_{i}=3 \mid v_{i}\right)=1-\theta\left(\mu-\alpha_{0}-v_{i} \gamma\right)
\end{gathered}
$$

where $v_{i}=\left[\mathrm{FIN}_{j}, \mathrm{FCAP}_{j} \mathrm{LOC}_{j}, \mathrm{INF}_{j}, \mathrm{STATUS}_{j}\right], \gamma=\left[\alpha_{1}, \beta_{k}, \mu_{l}, \phi_{p}, \lambda_{m}\right], \theta$ is the logistic distribution function and $\mu$ is the additional intercept that differentiates category 1 from category 2 . For all probabilities to be positive, $\mu$ should be greater than 0 .

We estimate the model using the maximum likelihood method. ${ }^{15}$ In all these estimations, we use firms as units of analysis.

\section{Descriptive statistics and results}

\subsection{Descriptive statistics}

We begin the empirical analysis by presenting the summary statistics in Table 1 for the dependent variable and the independent variables used in our analysis. ${ }^{16}$ In our data set, an average firm employs more than one worker; 32.5 per cent of firm owners face shortage of capital, and 27 per cent of firms undertake work on a contract basis. Very few firms received any assistance towards training and marketing from the government in the period 20012011. Only 11 per cent of firms in our data set have registered under any act or authority. Urban enterprises constitute 32 per cent of total firms surveyed. About a fifth (18 per cent) of firms have access to electricity connection but only 3.8 per cent of firms maintain accounts. Notably, more than a fifth of firm owners feel that their firms are expanding.

Table 1 also reports the summary statistics for district-level variables included in our analysis. On average, SCs and STs constitute 24 per cent of the total population at the district level. Average educational attainment is found to be considerably lower at the district level. The percentage of population that has attained pre-primary or primary levels of education is very low at 30 per cent while the share of people with post-secondary education is estimated at about 24 per cent. Interestingly, 66 per cent of districts are connected to a national highway or a broad-gauge railway line.

We also present the firm-level characteristics across the three enterprise types, PHEs, MHEs and NHEs in Table 2. PHEs form 85.8 per cent of total firms in our data set while MHEs and NHEs constitute only 10.4 per cent and 3.8 per cent of total firms, respectively. We find little variation across enterprise types in percentage of firms that are financially constrained. Urban areas account for more than 60 per cent of MHEs and NHEs and less than 30 per cent of PHEs. The percentage of firms that are registered under any act or authority in our data set increases with the size of the firm. It varies from 5 per cent in PHEs to a massive 55 per cent in NHEs. Concomitant to the picture at the all-enterprise-type level, very few PHEs, MHEs and NHEs receive any training and marketing assistance from the government. More than 30 per cent of NHEs, 11 per cent of MHEs and 2 per cent of PHEs claim that they maintain regular accounts. While comparing the access to infrastructure between small and large firms, we observe a clear bias toward large firms. For instance, 30 per cent of NHEs and 28 per cent of MHEs reported to have electricity access as opposed to 16 per cent of PHEs. A similar picture can be discerned when we consider access to a major transportation link, availability of better roads and availability of human capital. These summary statistics suggest that these variables seem to have an effect on the 
Table 1 Summary statistics—firm attributes, 2000-2001 to 2010-2011

\begin{tabular}{|c|c|c|c|c|c|}
\hline Variables & Number & Mean & SD & Min & Max \\
\hline \multicolumn{6}{|c|}{ Dependent variable ${ }^{a}$} \\
\hline ENTYP & 294,736 & 1.180350 & 0.473707 & 1 & 3 \\
\hline \multicolumn{6}{|l|}{ Finance $^{b}$} \\
\hline CAPSHOR & 294,736 & 0.324626 & 0.468236 & 0 & 1 \\
\hline \multicolumn{6}{|l|}{ Firm capabilities ${ }^{c}$} \\
\hline LINKAGE & 294,736 & 0.276420 & 0.447228 & 0 & 1 \\
\hline ASSISTANCE & 294,736 & 0.004402 & 0.066202 & 0 & 1 \\
\hline ACMAINT & 294,736 & 0.038159 & 0.191581 & 0 & 1 \\
\hline REGIS & 294,736 & 0.110029 & 0.312927 & 0 & 1 \\
\hline \multicolumn{6}{|c|}{ Locational variables $^{d}$} \\
\hline LOCATION & 294,736 & 0.329175 & 0.469914 & 0 & 1 \\
\hline URBAN & 294,736 & 0.313830 & 0.366611 & 0 & 1 \\
\hline TRANSPORT & 294,736 & 0.820579 & 0.383705 & 0 & 1 \\
\hline DISTANCE & 294,736 & 254.7668 & 179.2991 & 0 & 1010 \\
\hline \multicolumn{6}{|c|}{ Infrastructure and human capital variables ${ }^{e}$} \\
\hline ELEC & 294,736 & 0.180913 & 0.384946 & 0 & 1 \\
\hline SHSCSTPOP & 294,736 & 0.241005 & 0.115686 & 0.026295 & 0.942542 \\
\hline PRIMEDU & 294,736 & 0.298052 & 0.063819 & 0.14919 & 1 \\
\hline MIDGRADEDU & 294,736 & 0.243946 & 0.094608 & 0.068002 & 0.964556 \\
\hline ROADVILLG & 281,606 & 0.663063 & 0.239142 & 0.129032 & 1 \\
\hline \multicolumn{6}{|c|}{ Other control variables ${ }^{\mathrm{f}}$} \\
\hline STATUS & 294,736 & 0.211609 & 0.408450 & 0 & 1 \\
\hline
\end{tabular}

We applied frequency weights provided by the NSSO to compute descriptive statistics. Source: our calculations, from NSSO unit-level data for 2000-2001, 2005-2006 and 2010-2011 and the 2001 Census of India

a The dependent variable ENTYP is an ordered categorical variable taking values 1 to 3 ( $1=\mathrm{PHE}, 2=\mathrm{MHE}$ and $3=\mathrm{NHE})$ denoting the type of the firm

${ }^{b}$ Finance variable: CAPSHOR takes the value 1 if the firm faces a constraint and 0 if it does not

CVariables representing firm capabilities: LINKAGE is coded as 1 if the firms work for a contractor and 0 if they do not; ASSISTANCE takes the value 1 if the firms received any assistance from the training and towards marketing and 0 if they state that they did not receive any such assistance; ACMAINT assumes the value 1 if the firms maintain a regular account and 0 if not; and REGIS takes the value 1 if they have registered under any act and 0 if they did not

dLocational variables: LOCATION takes the value 1 if the firms are located in urban areas and 0 if they are located in rural areas; URBAN is a district-level measure representing the level of urbanisation in the district as measured by the share of urban population in total population; TRANSPORT takes the value 1 if a national highway or a broad-gauge line passes through the district and 0 if neither of them passes through the district; and DISTANCE signifies the remoteness of the district as captured by the distance of the district from the state capital

eHuman capital variables: ELEC takes the value 1 if it has access to electricity and 0 if it lacks access to it; SHSCSTPOP represents the proportion of SC/ST population in total population; PRIMEDU captures the proportion of individuals who are educated at the primary level or below; MIDGRADEDU stands for the proportion of individuals educated at the secondary level and above; and ROADVILLG represents the share of villages with paved approach road in total villages fOther control variables: STATUS takes the value 1 if the firm has been expanding and 0 if the firm has been stagnant or contracting

likelihood of a firm being a NHE or a MHE as compared to a PHE. In the analysis that follows, we have made an attempt to capture the relative importance of these variables on firm transition in the informal sector.

\subsection{Regression results}

Table 3 presents the estimates of the ordered logit regression model given in Eq. (1). ${ }^{17}$ In all, we estimate five specifications of Eq. (1). In model 1, we introduce the CAPSHOR variable. In model 2 , we include industry and year dummies. We then introduce variables representing firm capabilities in model 3 . We bring in locational variables 
Table 2 Type-wise characteristics of firms (mean values), 2000-2001 to 2010-2011

\begin{tabular}{llll}
\hline Variable & PHE & MHE & NHE \\
\hline $\begin{array}{l}\text { Number of firms (\%) } \\
\text { Finance }\end{array}$ & $42,144,550(85.8)$ & $5,097,809(10.4)$ & $1,880,768(3.8)$ \\
CAPSHOR & & & \\
Firm capabilities & 0.323683 & 0.343872 & 0.293587 \\
LINKAGE & 0.287184 & 0.195093 & 0.255651 \\
ASSISTANCE & 0.004187 & 0.004479 & 0.009014 \\
ACMAINT & 0.017898 & 0.108886 & 0.300479 \\
REGIS & 0.055622 & 0.396536 & 0.552625 \\
Locational variables & & & \\
LOCATION & 0.283207 & 0.607179 & 0.605701 \\
URBAN & 0.294591 & 0.407482 & 0.491078 \\
TRANSPORT & 0.811359 & 0.865495 & 0.905439 \\
DISTANCE & 259.8309 & 228.0022 & 213.8350 \\
Infrastructure and human capital variables & 0.163424 & 0.280594 & 0.302623 \\
ELEC & 0.245985 & 0.214567 & 0.201067 \\
SHSCSTPOP & 0.298373 & 0.294592 & 0.300239 \\
PRIMEDU & 0.236657 & 0.283031 & 0.301347 \\
MIDGRADEDU & 0.649164 & 0.741838 & 0.783849 \\
ROADVILG & 0.198716 & & \\
Other control variables & & 0.276805 & \\
STATUS & & & \\
\hline
\end{tabular}

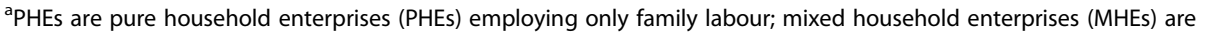
enterprises that employ at least one hired labour on a regular basis, but the total number of workers (including family labour) do not exceed five; and non-household enterprises (NHEs) are those employing 6-9 workers of which at least one would be a hired worker

bother variables are as defined in the notes to Table 1

Source: same as in Table 1

along with STATUS as the control variable in model 4. We also include infrastructure and human capital variables in model 5.

Our results unequivocally suggest that credit availability plays a positive role in the upward progression of firms in the informal sector. The coefficient of CAPSHOR variable is negative and significant at the 1 per cent level across all five models indicating a negative relationship between financial constraints and firm transition in the informal manufacturing sector in India. This gives credence to the fact that with the easing of financial constraint, a firm is likely to expand and move to the next size classes.

The results with respect to the influence of firm capabilities on firm transition are in line with our expectation. LINKAGE is positively associated with firm transition. The firms that are on contract are more likely to expand in size, which is quite plausible as these firms will be needing the specialised skills that outside workers bring to perform the tasks assigned by the parent firms. Our conjecture is further strengthened by the fact that, relatively, a higher share of NHEs work as subcontractors for large firms as compared to PHEs and MHEs (Table 1). ACMAINT is positively correlated with firm transition suggesting that the progression of firms to immediate size class is more evident among firms that maintain regular accounts. This result is in line with that of Acar (1993) who shows that sound accounting practices are an important factor 
Table 3 Results: ordered logistic regression estimates

\begin{tabular}{|c|c|c|c|c|}
\hline \multirow[b]{2}{*}{ Variables } & \multirow[b]{2}{*}{ Model 1} & \multicolumn{3}{|c|}{ Dependent variable: ENTYP } \\
\hline & & Model 2 & Model 3 & Model 4 \\
\hline \multicolumn{5}{|l|}{ Finance } \\
\hline CAPSHOR & $-0.116^{* * *}(0.013)$ & $-0.059^{* * *}(0.014)$ & $-0.054^{* * *}(0.014)$ & $-0.038^{* * *}(0.015)$ \\
\hline \multicolumn{5}{|l|}{ Firm capabilities } \\
\hline LINKAGE & & $0.237^{* * *}(0.015)$ & $0.112^{* * *}(0.016)$ & $0.057^{* * *}(0.017)$ \\
\hline ASSISTANCE & & $0.365^{* * *}(0.080)$ & $0.460^{* * *}(0.081)$ & $0.550^{* * *}(0.082)$ \\
\hline ACMAINT & & $1.466^{* * *}(0.021)$ & $1.352^{* * *}(0.022)$ & $1.296^{* * *}(0.023)$ \\
\hline REGIS & & $2.227^{* * *}(0.014)$ & $1.972^{* * *}(0.014)$ & $1.860^{* * *}(0.015)$ \\
\hline \multicolumn{5}{|l|}{ Locational variables } \\
\hline LOCATION & & & $0.882^{* * *}(0.013)$ & $0.751^{* * *}(0.014)$ \\
\hline URBAN & & & $0.219^{* * *}(0.014)$ & $0.109^{* * *}(0.016)$ \\
\hline TRANSPORT & & & $0.215^{* * *}(0.018)$ & $0.143^{*}(0.019)$ \\
\hline DISTANCE & & & $-0.001^{* * *}(0.000)$ & $-0.0004^{* * *}(0.000)$ \\
\hline \multicolumn{5}{|c|}{ Infrastructure and human capital variables } \\
\hline ELEC & & & & $0.620^{* * *}(0.015)$ \\
\hline SHSCSTPOP & & & & $0.039(0.067)$ \\
\hline PRIMEDU & & & & $-1.771^{* * *}(0.119)$ \\
\hline MIDGRADEDU & & & & $1.062^{* * *}(0.084)$ \\
\hline ROADVILLG & & & & $1.147^{* * *}(0.038)$ \\
\hline \multicolumn{5}{|l|}{ Other control variables } \\
\hline STATUS & & & $0.474^{* * *}(0.014)$ & $0.519^{* * *}(0.014)$ \\
\hline Industry dummy & Y & Y & Y & Y \\
\hline Year dummy & Y & Y & Y & Y \\
\hline$N$ & 294,733 & 294,733 & 294,733 & 281,603 \\
\hline Pseudo R2 & 0.06 & 0.19 & 0.21 & 0.22 \\
\hline Log likelihood & $-136,052.18$ & $-117,687.89$ & $-113,759.62$ & $-103,482.87$ \\
\hline Chi-squared & $17,606.59$ & $54,335.17$ & $62,191.71$ & $58,371.55$ \\
\hline Prob > chi-squared & 0.0000 & 0.0000 & 0.0000 & 0.0000 \\
\hline
\end{tabular}

Source: same as in Table 1

${ }^{a}$ Sampling weights have been applied for estimation, which implies a population of about 49.1 million observations (all survey rounds together)

${ }^{\mathrm{b}}$ Figures in parentheses are robust standard errors. (i) ${ }^{* *}$ indicate significance at minimum $1 \%$ level

'See notes to Table 1 for variable definitions

associated with firm growth. As conjectured, REGIS is also positively associated with firm transition. This shows that firms that are part of an organisation or authority or those registered under any act tend to grow in size as against firms that are neither a member of an organisation nor registered under any act. There is, however, less evidence that assistance provided to firms play a positive role in the upward progression of firms as the coefficient for ASSISTANCE is significant only in one of the estimations. Of course, the raw data would have anticipated this result; very few firms (a meagre 0.4 per cent) in the data set report that they received assistance in the form of training and marketing. ${ }^{18}$

Our results also forcefully point to the significant role of locational and geographical variables on firm transition in the informal sector. The coefficient of LOCATION is positive and highly significant in all our estimations suggesting that upward progression 
is faster among firms that are located in urban areas, cities and towns as compared to their counterparts in rural towns and villages. We also find that firms are more likely to make the transition to immediate size classes in more urbanised districts. This is clearly evident from the positive and highly significant coefficient of URBAN. This indicates that the demand-side factors are very important for firm transition as in more urbanised districts, there will be greater demand for manufactured products. Our results also indicate that availability of better transport infrastructure at the district level leads to more firms shifting to larger enterprise types. Access to better transport infrastructure improves market accessibility for small firms, which will have an impact on their average firm size and their subsequent growth (Tybout 2000). We also find a significant negative relationship between remoteness of the district (DISTANCE) and firm transition. The coefficient of DISTANCE is significant and negative in all specifications, indicating that graduation of firms to bigger sizes decreases with increase in the distance of the district from the state capital. Our results thus suggest that reduction in transport costs captured through lesser distance and better transport infrastructure is very important for firm transition as firms tend to benefit from reduced factor costs, increased access to specialised labour, and general agglomeration economies (Shiferaw et al. 2013).

Results of our study also confirm the pivotal role of infrastructure and human capital on firm transition. The coefficient of ELEC is positive and significant indicating that provision of quality electricity is an important dimension of infrastructure affecting firm expansion in the informal sector. We notice a negative relationship between PRIMEDU and firm transition, possibly highlighting the effect of the constraints emanating from lower levels of human capital on firm transition. The positive and significant coefficient of MIDGRADEDU confirms our conjecture on the positive role of human capital on firm transition. On the other hand, SHSCSCTPOP included in the equation to gauge the effect of social backwardness on firm transition is not significant in all our specifications though it gives the expected negative sign.

To lend exact interpretation of the magnitude of change of explanatory variables on firm transition, we compute marginal effects of explanatory variables on firm transition. These results are presented in Table 4. We start with the variables representing firm capabilities as they are the most important determinants of firm growth, according to our study. Our estimates of marginal effects suggest that a registered firm has a 30 per cent more chance of being an MHE and a 12.2 per cent more chance of being an NHE as compared to an unregistered firm. At the same time, the likelihood of a registered firm continuing as a PHE decreases by 42 per cent. If a firm maintains accounts, the probability of it being an MHE and an NHE goes up by 17.3 per cent and 14.6 per cent, respectively, while of being a PHE drops by 32 per cent. The firms that are tied through subcontracting arrangements are 2 per cent more likely to be MHEs and NHEs but 4.4 per cent less likely to be PHEs.

Relative to firms in rural areas, urban firms have a greater chance of being in the larger firm category (Table 4). The likelihood of an urban firm being an MHE improves by 8 per cent, and its continuance as a PHE reduces by 8 per cent Firms in more urbanised areas are 3.7 per cent less likely to be PHEs, but they are 2.3 per cent likely to be MHEs and 1.4 per cent more likely to be NHEs.

Our results also suggest that improvement in infrastructure can significantly accelerate firm transition in the informal sector (Table 4). We find that firms in villages with 
Table 4 Marginal effects of explanatory variables on firm transition

\begin{tabular}{llll}
\hline Variables & PHE & MHE & NHE \\
\hline $\begin{array}{l}\text { Finance } \\
\text { CAPSHOR }\end{array}$ & $0.00526^{* *}(0.00233)$ & $0.00011(0.00212)$ & $-0.00537^{* * *}(0.00078)$ \\
Firm capabilities & & & \\
LINKAGE & $-0.04377^{* * *}(0.00284)$ & $0.02147^{* * *}(0.00255)$ & $0.02230^{* * *}(0.00116)$ \\
ASSISTANCE & $-0.03355^{* *}(0.01523)$ & $0.03084^{* * *}(0.01197)$ & $0.00271(0.00424)$ \\
ACMAINT & $-0.31916^{* * *}(0.00486)$ & $0.17300^{* * *}(0.00456)$ & $0.14616^{* * *}(0.00300)$ \\
REGIS & $-0.42216^{* * *}(0.00258)$ & $0.30054^{* * *}(0.00249)$ & $0.12162^{* * *}(0.00173)$ \\
Locational variables & & & \\
LOCATION & $-0.08004^{* * *}(0.00203)$ & $0.08471^{* * *}(0.00189)$ & $-0.00467^{* * *}(0.00075)$ \\
URBAN & $-0.03691^{* * *}(0.00251)$ & $0.02252^{* * *}(0.00222)$ & $0.01439^{* * *}(0.00077)$ \\
TRANSPORT & $-0.01718^{* * *}(0.00255)$ & $0.01437^{* * *}(0.00238)$ & $0.00281^{* * *}(0.00094)$ \\
DISTANCE & $0.00004^{* * *}(0.00001)$ & $-0.00005^{* * *}(0.00001)$ & $0.00001^{* * *}(0.00000)$ \\
Infrastructure and human & capital variables & $0.11440^{* * *}(0.00245)$ & $0.03437^{* * *}(0.00109)$ \\
ELEC & $-0.14876^{* * *}(0.00264)$ & $0.01014(0.00912)$ & $-0.00198(0.00359)$ \\
SHSCSTPOP & $-0.00815(0.00979)$ & $-0.17632^{* * *}(0.01807)$ & $-0.05145^{* * *}(0.00671)$ \\
PRIMEDU & $0.22778^{* * *}(0.01981)$ & $0.07998^{* * *}(0.01195)$ & $0.04500^{* * *}(0.00547)$ \\
MIDGRADEDU & $-0.12498^{* * *}(0.01330)$ & $0.16279^{* * *}(0.00498)$ & $0.05151^{* * *}(0.00200)$ \\
ROADVILLG & $-0.21430^{* * *}(0.00536)$ & $0.08483^{* * *}(0.00236)$ & $0.02554^{* * *}(0.00099)$ \\
Other controls & $\left.-0.11038^{* * *} 0.00253\right)$ &
\end{tabular}

Source: same as in Table 1

aThese estimates presented are generalised ordered logit model estimates

${ }^{b}$ Figures in parentheses are robust standard errors

$C_{* * *},{ }^{* *}$ and ${ }^{*}$ stand respectively for level of significance at 1, 5 and $10 \%$ levels

${ }^{d}$ See notes to Table 3 for the definitions of variables

better road infrastructure (captured through ROADVILLG) are 16.3 per cent more likely to be MHEs and 5.2 per cent more likely to be NHEs. Their location in such villages also reduce the probability of them becoming PHEs by 21.4 per cent. When it comes to provision of electricity, we find that firms that are located in districts with access to power have an 11.4 per cent more chance of becoming MHEs and a 3.4 per cent more chance of becoming NHEs. Access to power also decreases their chance of continuing as PHEs by 14.9 per cent. Confirming the positive role of human capital on firm transition, our results suggest that firms located in districts with higher proportion of individuals with postsecondary education have an 8 per cent and 4.5 per cent greater chance of becoming MHEs and NHEs, respectively, as compared to those located in other districts. The probability of such firms continuing as PHEs also reduces by 12.5 per cent.

Like other studies, we also find that access to finance is an important determinant of firm expansion in the sector. However, we also find that, compared to variables representing firm capabilities, infrastructure and human capital, access to credit plays a less important role in firm transition. Our estimates show that financial constraints increase the probability of a firm being a PHE by 0.5 per cent and reduce the likelihood of it becoming an NHE by 0.5 per cent. ${ }^{19}$

There are two limitations of our econometric analysis. Firstly, as mentioned earlier, we do not have a panel of informal firms, so cannot follow the transition of a firm from being a PHE to a MHE or from a MHE to a NHE. Therefore, we can interpret our 
results as showing the likelihood that a firm is a PHE, MHE or NHE for a given set of firm and district characteristics. Without panel data, we cannot establish causality between firm and district characteristics and the transition of the firm from a PHE to a MHE or NHE. Secondly, there are concerns of possible endogeneity associated with some of the variables identified as determinants of firm transition, especially the variables used to represent 'firm capabilities'. With regard to ASSISTANCE, it is possible that a firm with a larger size are more likely to get assistance from institutional and non-institutional sources. Similar arguments can be made for ACMAINT and REGIS as well. The lack of suitable instruments for these explanatory variables severely limits our capacity to devise a strategy to address the issue of endogeneity. One way out is to estimate the regressions with and without these explanatory variables. We performed this exercise and our results are robust to these alternate specifications.

\section{Conclusions}

In this paper, we examine the determinants of firm transition in the informal manufacturing sector, and try to understand why so few small family firms (PHEs) which are the predominant type of firms in the informal sector, fail to make the transition to the larger firms that employ non-family labour (NHEs and MHEs) in developing economies. We use a very rich firm-level data set drawn from representative all-India surveys of the informal manufacturing sector for our empirical analysis.

Our findings suggest that firm capabilities such as the ability of firms to maintain accounts and whether firms are registered under any Act or authority are associated with the likelihood of firm transition across different size categories. In addition, location, infrastructure and human capital are also important. In contrast, credit availability plays a lesser role in firm transition.

Several policy implications follow from our results. Firstly, policymakers can provide greater incentives for firms to register with the relevant authorities as well as simplifying the registration process. Secondly, the government can encourage skill upgradation among owners and managers of informal firms and provide targeted support to family firms for training in account maintenance. Thirdly, there should be greater provision of paved roads and electricity to rural areas in India. Finally, there needs to be a stronger emphasis on human capital formation, especially in the provision of secondary schools in rural areas, and on adult education. Our results suggest that while there are clear impediments to firm growth in the Indian informal manufacturing sector, a more supportive policy environment would go a long way in easing these impediments. Given that the majority of India's manufacturing workforce are concentrated in low-productivity family firms in the informal sector, this would allow a route out of poverty for many of the workers and employers in these firms and contribute to a more dynamic manufacturing sector in India.

\section{Endnotes}

${ }^{1}$ In contrast, as Gollin (2008) notes, small enterprises play a minor role in advanced market economies.

${ }^{2}$ As Breman (2010, p. 99) notes, the movement of self-employed workers in family firms to owner-managers of firms which employ wage labour 'turns out to be anything but exceptional'. 
${ }^{3}$ Our definition of the informal sector corresponds to a conceptualisation of informal firms as those that are minimally registered and below size thresholds for taxation or labour regulation. As Harriss-White (2010) notes, in this definition of informality, 'it is not the intrinsic characteristic of activities, but rather the boundaries of state regulation, that determine the degree of informality' (p. 171).

${ }^{4}$ In the enterprise survey by the World Bank, $35 \%$ of the small firms rate cost of finance as a major growth constraint and $30 \%$ rate access to finance as a major growth constraint (Beck 2007).

${ }^{5}$ The practice of demarcating establishments that employ hired worker into MHEs and NHEs is to some extent arbitrary, determined by the practices of the National Sample Survey Organisation (NSSO), the agency which is instrumental in carrying out large-scale nationwide surveys on the informal sector. However, as is argued by Mazumdar and Sarkar (2008), such a demarcation stands to reason as an establishment enters into a more modern economic relationship when it graduates to a six-worker employment size.

${ }^{6}$ As is the general practice in the literature, labour productivity is measured as the ratio of real gross value added to the number of workers. We deflated nominal gross value added by wholesale price index (WPI) for manufactured products to arrive at the real gross value added. Real gross value added figures are computed at the 1993-1994 prices.

${ }^{7}$ The two terms 'informal sector' and 'unorganised sector' are used interchangeably in the Indian context.

${ }^{8}$ The NSSO survey data for the years 1994-1995 does not provide information for the variables CAPSHOR, CONTRACT, ASSISTANCE, ACMAINT, REGIS and ELEC.

${ }^{9}$ The 15 states included are Andhra Pradesh (AP), Assam, Bihar, Gujarat, Haryana, Karnataka, Kerala, Madhya Pradesh (MP), Maharashtra, Orissa, Punjab, Rajasthan, Tamil Nadu (TN), Uttar Pradesh (UP) and West Bengal (WB).

${ }^{10} \mathrm{By}$ employing the ordered logit model (OLM), we are expected to capture the probability that a firm would choose to be in either of these enterprise types in the presence of the given constraints. In short, the model would help us in computing the probabilities of a unit falling in the three enterprise types. For a detail discussion on the use of OLM, see Gebreeyesus and Mohnen (2013).

${ }^{11} \mathrm{We}$ also used an alternate measure of firm growth in the informal sector which is continuous in form rather than being a categorical variable. This measure is the share of hired workers in total workers of a firm. The results hold when we use this measure instead of our categorical variable.

${ }^{12}$ Note that the registration with acts/authorities of the state and municipal governments is not the same as registering with the official agency under the Factories Act (that is, when the firm becomes a formal entity). State and municipal governments and cooperative authorities provide bespoke support to informal firms (or certain categories of them, such as enterprises making traditional crafts and handicrafts) in their jurisdiction or require them to pay fees or limited insurance benefits to their employees, for which these firms need to register under the relevant act/authority.

${ }^{13}$ India's Scheduled Castes (SCs) and Scheduled Tribes (STs) remain socially excluded from the mainstream due to the persistence of caste and other forms of social discrimination. The incidence of headcount poverty among SCs and STs was 21 
and 15 percentage points higher, respectively, than for the rest of the population in 2009-2010 (Himanshu and Sen 2013), and SC and ST households are much more likely to face barriers to access to credit and human capital acquisition and are less likely to be owners/managers of non-family firms than other social groups (Thorat and Newman 2010). Thus, districts with high SC/ST presence are less likely to see the mobility of family firms to non-family firms.

${ }^{14}$ As we include district-level variables among the explanatory variables, we do not include district-specific effects in our estimations. Our results are robust to clustering the standard errors at the industry level.

${ }^{15}$ The ordered logit model, however, assumes proportional odds between the different categories, which imply that the relationship between each pair of outcomes is the same for all variables. We, therefore, also test for this assumption of proportional odds by comparing the estimates from the ordered logit model with those of the generalised ordered logit model, where not just the intercept but also the coefficients vary by category of the dependent variable. However, we found no change in our results. For the sake of brevity, we do not report these results but these can be obtained from the authors upon request.

${ }^{16}$ Throughout this paper, we apply frequency weights provided by the NSSO to compute descriptive statistics and perform regression estimations, which is often advocated when estimating population averages from the sample data (Solon et al. 2013).

${ }^{17}$ We have also estimated Eq. (1) for each year and find that the results are consistent across years. Hence, the results for the pooled sample are being presented. We do not report these results due to space constraints. The results can be obtained from the authors upon request.

${ }^{18}$ We have noted from Table 1 that very few firms received assistance. Therefore, we have also estimated the ordered logit model excluding ASSISTANCE and found no change in the results.

${ }^{19} \mathrm{~A}$ number of studies have also highlighted the less important role of credit access on firm growth (Daniels and Mead 1998; Johnson et al. 2000; McPherson and Rous 2010). For instance, McPherson and Rous (2010) argue that once we control for unobservable characteristics of firms as well as other observable factors, credit does not make any appreciable effect on a firm's growth rate. According to them, the sector in which a firm operates, its initial size, its age and certain unobservable characteristics of the firm and the community in which it operates are more important determinants of small firm growth than availability of credit.

Competing interests

The IZA Journal of Labor \& Development is committed to the IZA Guiding Principles of Research Integrity. The authors declare that they have observed these principles.

Acknowledgements

This paper forms part of a larger study funded by the International Growth Centre (IGC), London School of Economics. We are thankful to the IGC for the financial support. We are also thankful to the Central Statistical Organization for providing us access to the data and to Professor $\mathrm{K} L$ Krishna for the many suggestions and comments. We are also grateful to an anonymous referee and the editor for the insightful comments. The usual disclaimers apply.

Responsible editor: Hartmut F. Lehmann

Author details

${ }^{1}$ Department of Economics, Sikkim University, Gangtok, Sikkim 737102, India. ${ }^{2}$ Global Development Institute, University of Manchester, Manchester, UK. ${ }^{3}$ Global Development Institute, Oxford Road, Manchester M13 9PL, UK. 
Received: 14 September 2015 Accepted: 22 February 2016

Published online: 27 May 2016

\section{References}

Acar A (1993) The impact of key internal factors on firm performance: an empirical study of small Turkish firms. Journal of Small Business Management 31(4):86-92

Arend RJ (2014) Entrepreneurship and dynamic capabilities: how firm age and size affect the 'capability enhancement-SME performance' relationship. Small Bus Econ 42(1):33-57

Aterido R, Hallward-Driemeier M, Pages C (2011) Big constraints to small firms' growth? Business environment and employment growth across firms. Economic Development and Cultural Change 59(3):609-647

Beck T (2007) Financing constraints of SMEs in developing countries: evidence, determinants and solutions, Mimeo, School of Economics and Management, Tilburg University

Beck T, Demirgüç-Kunt A, Maksimovic V (2005) Financial and legal constraints to firm growth: does firm size matter? Journal of Finance 60:137-177

Beck T, Demirgüç-Kunt A, Laeven L, Levine R (2008) Finance, firm size, and growth. Journal of Money, Credit and Banking 40(7):1379-1405

Berry A, Rodrigues E, Sandee H (2002) Firm and group dynamics in the small and medium enterprise sector in Indonesia. Small Business Economics 18(1-3):141-161

Bigsten A, Gebreeyesus M (2007) The small, the young, and the productive: determinants of manufacturing firm growth in Ethiopia. Economic Development and Cultural Change 55(4):813-840

Binks M, Ennew C (1996) Growing Firms and the Credit Constraint. Small Business Economics 8(1):17-25

Breman J (2010) Outcast labour in India: circulation and informalisation of the workforce at the bottom of the economy. Oxford University Press, New Delhi

Brown JD, Earle JS, Lup D (2005) What makes small firms grow? Finance, human capital, technical assistance, and the business environment in Romania. Economic Development and Cultural Change 54(1):33-70

Burki AA, Terrell D (1998) Measuring production efficiency of small firms in Pakistan. World Development 26(1):155-169

Catao LAV, Pages C, Rosales MF (2009) Financial dependence, formal credit and informal jobs, IDB Working Paper 118. Inter-American Development Bank, Washington

Daniels L, Mead DC (1998) The contribution of small enterprises to household and national income in Kenya. Economic Development and Cultural Change 47(1):45-71

De Neve G (2005) The everyday politics of labour: working lives in India's informal economy. Social Science Press, New Delhi

Dollar D, Hallward-Driemeier M, Mengistae T (2005) Investment climate and firm performance in developing economies. Economic Development and Cultural Change 54(1):1-31

Gang I (1992) Small firm 'presence' in Indian manufacturing. World Development 20(9):1377-1389

Gebreeyesus M, Mohnen P (2013) Innovation performance and embeddedness in networks: evidence from the Ethiopian footwear cluster. World Development 41:302-16

Giunta A, Annamaria N, Domenico S (2012) Subcontracting in Italian industry: labour division, firm growth and the north-south divide. Regional Studies 46(8):1067-1083

Gollin D (2008) Nobody's business but my own: self-employment and small enterprise in economic development. Journal of Monetary Economics 55(2):219-233

Harriss-White B (2010) Work and wellbeing in informal economies: the regulative roles of institutions of identity and the state. World Development 38(2):170-183

Hill H (1985) Subcontracting, technological diffusion and the development of small enterprise in Philippine manufacturing. The Journal of Developing Areas 19(2):245-262

Himanshu and K. Sen (2013) Poverty in India: measurement, patterns, and determinants, Mimeo.

Holl A (2012) Market potential and firm-level productivity in Spain. Journal of Economic Geography 12(6):1191-1215

Hsieh C, Klenow PJ (2009) Misallocation and manufacturing TFP in China and India. The Quarterly Journal of Economics 124(4):1403-1448

Johnson S, McMillan J, Woodruff C (2000) Entrepreneurs and the Ordering of Institutional Reform. Economics of Transition 8(1):1-36

Johnson S, McMillan J, Woodruff C (2002) Property rights and finance. American Economic Review 92(5):1335-1356

Kanbur R (2011) Avoiding informality traps. In: Ghani E (ed) Reshaping tomorrow: is South Asia ready for the big leap? Oxford University Press, New Delhi, pp 260-278

Kulshreshtha AC (2011) Measuring the unorganised sector in India. Review of Income and Wealth 57(s1):S123-S134

Kuntchev V, Ramalho R, Rodriguez-Meza J, Yang JS (2012) What have we learned from the enterprise surveys regarding access to finance by SMEs?, Research report, Enterprise Analyisis Unit of the World Bank, Washington DC

Lall S (1980) Vertical inter-firm linkages in LDCs: an empirical study. Oxford Bulletin of Economics and Statistics 42:203-226

Lall SV, Shalizi Z, Deichmann U (2004) Agglomeration economies and productivity in Indian industry. Journal of Development Economics 73(2):643-673

Liedholm C, Mead D (1999) Small enterprises and economic development: the dynamic role of micro and small enterprises. Routledge, London

Mazumdar D, Sarkar S (2008) Globalization, labour markets and inequality in India. Oxon, Routledge

McPherson MA, Rous JJ (2010) Access to finance and small enterprise growth: evidence from East Java. Journal of Developing Areas 43(2):159-172

Mead DM, Liedholm C (1998) The dynamics of micro and small enterprises in developing countries. World Development 26(1):61-74

Mean D (1984) Of contracts and subcontracts: small firms in vertically disintegrated production/distribution systems in LDCs. World Development 12(11-12):1095-1106

Nafziger EW, Terrell D (1996) Entrepreneurial human capital and the long-run survival of firms in India. World Development 24(4):689-696 
National Commission for Enterprises in the Unorganised Sector (NCEUS) (2007) Conditions of work and promotion of livelihood in the unorganised sector. Report submitted to the Government of India, New Delhi

NCEUS (2009) The challenge of employment in India: an informal economy perspective, report. Government of India, New Delhi

Nichter S, Goldmark L (2009) Small firm growth in developing countries. World Development 37(9):1453-1464

Ojah K, Gwatidzo T, Kaniki S (2010) Legal environment, finance channels and investment: the East African example. Journal of Development Studies 46(4):724-744

Oliveira B, Fortunato A (2006) Firm Growth and Liquidity Constraints: a Dynamic Analysi. Small Business Economics 27(2):139-156

Pais J (2008) Effectiveness of labour regulations in Indian industry. Bookwell Publishers, New Delhi

Penrose EG (1959) The theory of the growth of the firm. Wiley, New York

Raj RSN, Sen K (2016) Out of the shadows? The informal manufacturing in post-reform India, Delhi: Oxford University Press, Delhi

Rajan GR, Zingales L (1998) Financial dependence and growth. American Economic Review 88(3):559-586

Rice P, Venables AJ, Patacchini E (2006) Spatial determinants of productivity: analysis for the regions of Great Britain. Regional Science and Urban Economics 36(6):727-752

Rijkers B, Söderbom M, Loening $J L$ (2010) A rural-urban comparison of manufacturing enterprise performance in Ethiopia. World Development 38(9):1278-1296

Schmitz H (1982) Growth constraints on small-scale manufacturing in developing countries: a critical review. World Development 10(6):429-450

Schmitz H, Nadvi K (1999) Clustering and industrialisation: introduction. World Development 27(9):1503-1514

Sharma S (2014) Benefits of a registration policy for microenterprise performance in India. Small Business Economics 42(1):153-164

Sher PJ, Yang PY (2005) The effects of innovative capabilities and R\&D clustering on firm performance: the evidence of Taiwan's semiconductor industry. Technovation 25(1):1-82

Shiferaw A, Söderbom M, Siba E, Alemu G (2013) Road infrastructure and enterprise dynamics in Ethiopia, Working Paper No. 128. Department of Economics, College of William and Mary, Virginia

Solon G, Haider SJ, Wooldridge JM (2013) What are we weighting for? The Journal of Human Resources 50(2):301-316

Thorat S, Newman K (2010) Blocked by caste: economic discrimination in modern India. Oxford University Press, Delhi

Tybout JR (2000) Manufacturing firms in developing countries: how well do they do, and why? Journal of Economic Literature 38(1):11-44

Van der Sluis J, van Praag M, Vijverberg W (2005) Entrepreneurship selection and performance: a meta-analysis of the impact of education in developing economies. World Bank Economic Review 19(2):225-261

Variyam JN, Kraybill DS (1992) Empirical evidence on determinants of firm growth. Economics Letters 38(1):31-36 Winker P (1999) Causes and Effects of Financing Constraints at the Firm Level. Small Business Economics 12(2):169-81

Woodruff C (2012) The other half: What do(n't) we know about self-employment in LICs? paper presented in DFID/IZA

Workshop: growth and labour markets in low income countries: setting the research agenda, http://glm-lic.iza.org/file/ view/events/Paper_Woodruff_GLM_LIC.pdf; 26 January 2013

Woodruff C, Zenteno R (2007) Migration networks and microenterprises in Mexico. Journal of Development Economics 82(2):509-528

Yang C, Huang C (2005) R\&D, Size and Firm Growth in Taiwan's Electronics Industry. Small Business Economics 25(5):477-487

Yasuda T (2005) Firm growth, size, age and behaviour in Japanese manufacturing. Small Business Economics 24(1):1-15

\section{Submit your manuscript to a SpringerOpen ${ }^{\circ}$ journal and benefit from:}

- Convenient online submission

- Rigorous peer review

- Immediate publication on acceptance

- Open access: articles freely available online

- High visibility within the field

- Retaining the copyright to your article 